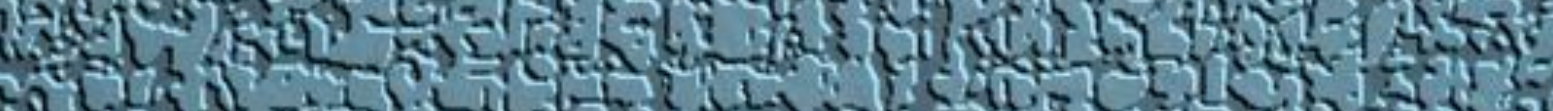

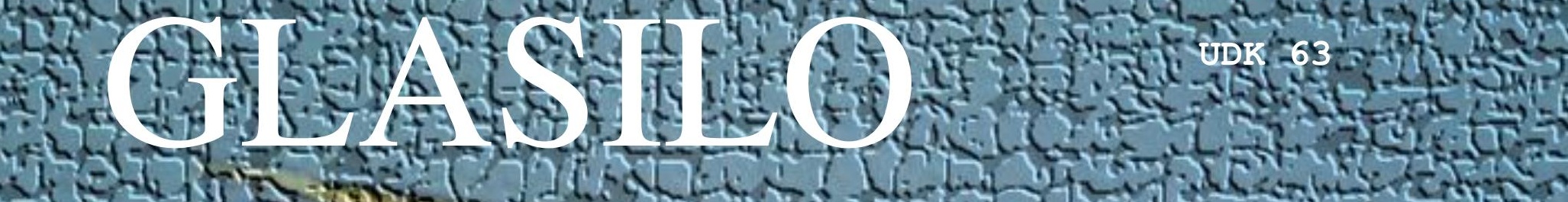

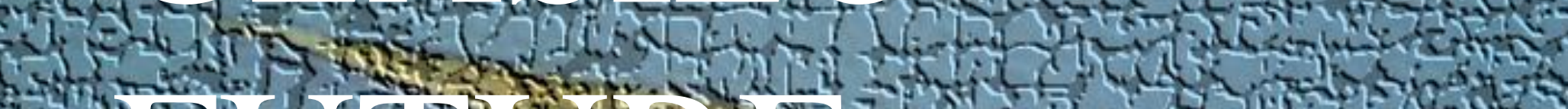
Ant

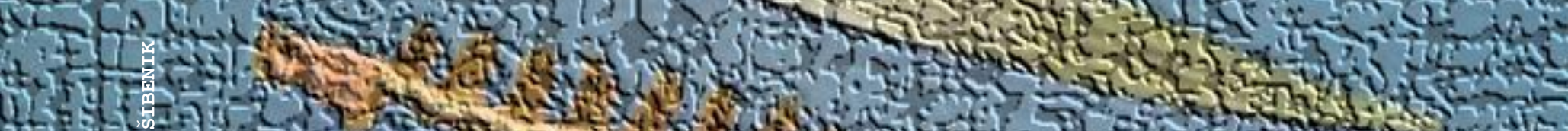

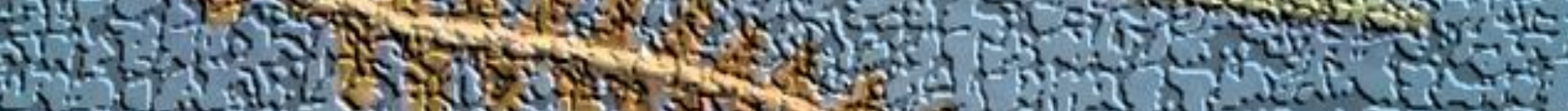
If

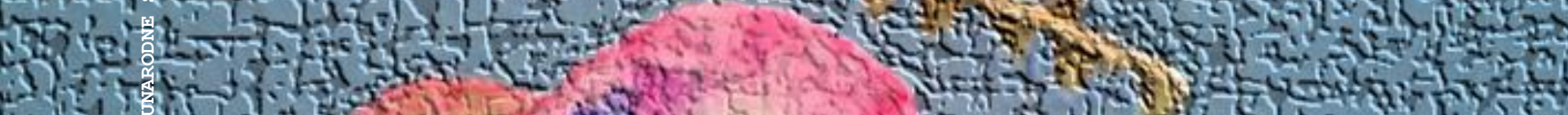

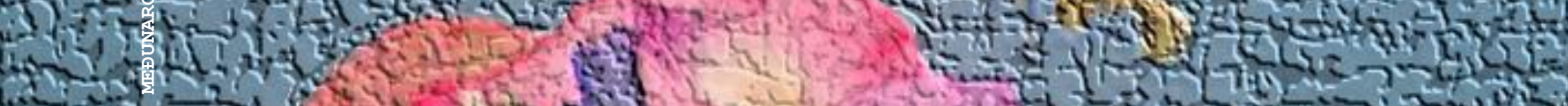

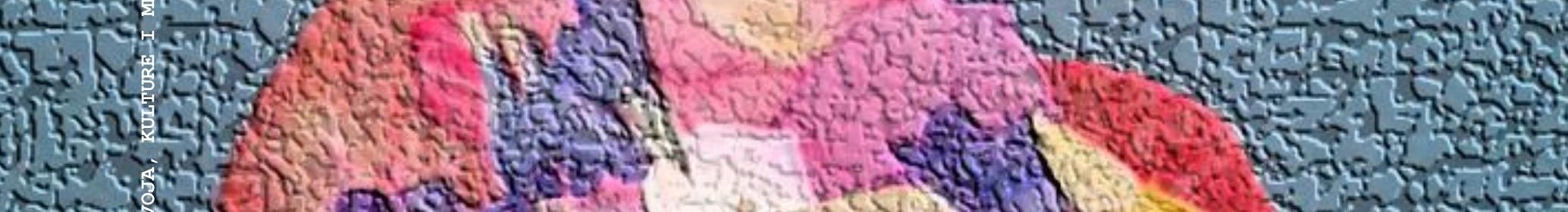
Nog

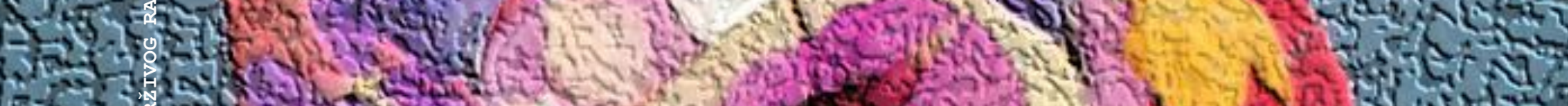

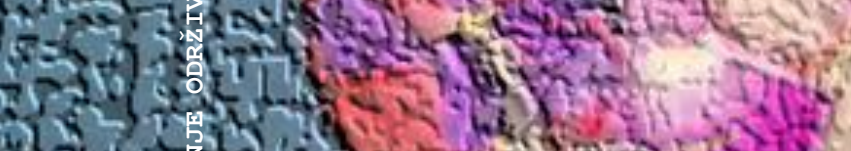
20. S. (2) (1)

1. (c) -

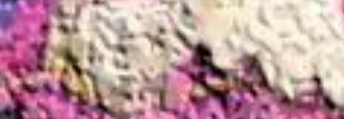
(3)

-1.

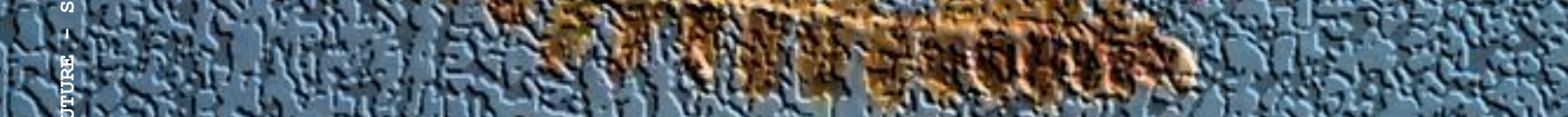
(n) So

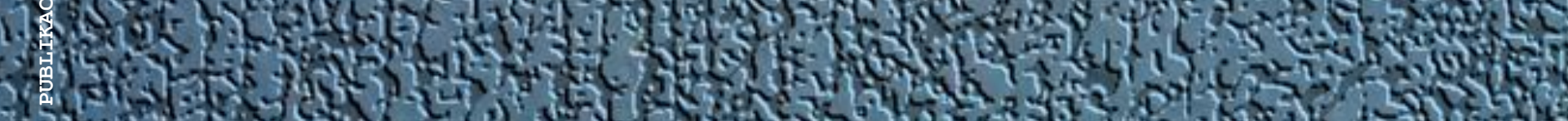
VoIUMgN 4 BRo $2-3$.

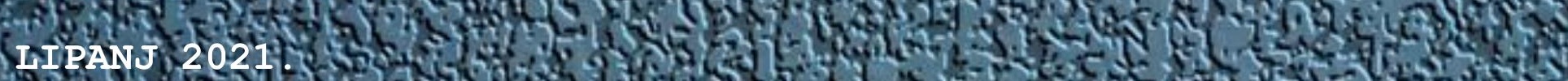

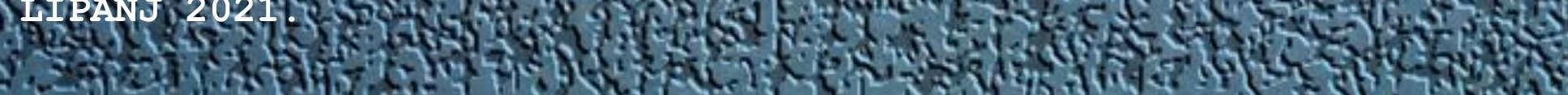




\section{Glasilo Future}

\section{Stručno-znanstveni časopis}

\section{Nakladnik: FUTURA}

\section{$F_{0 T} T_{0 R} A$}

Sjedište udruge: Šibenik
Adresa uredništva:

Bana Josipa Jelačića 13 a, 22000 Šibenik, Hrvatska / Croatia

㞗 / 息: +385 (0) 022218133

凹: urednistvo@gazette-future.eu / editors@gazette-future.eu

(3): www.gazette-future.eu

\section{Uređivački odbor / Editorial Board:}

Doc. dr. sc. Boris Dorbić, v. pred. - glavni i odgovorni urednik / Editor-in-Chief

Emilija Friganović, dipl. ing. preh. teh., v. pred. - zamjenica g. i o. urednika / Deputy Editor-in-Chief

Ančica Sečan, mag. act. soc. - tehnička urednica / Technical Editor

Antonia Dorbić, mag. art. - zamjenica tehničke urednice / Deputy Technical Editor

Prof. dr. sc. Željko Španjol

Mr. sc. Milivoj Blažević

Vesna Štibrić, dipl. ing. preh. teh.

Međunarodno uredništvo / International Editorial Board:

Prof. dr. sc. Kiril Bahcevandziev - Portugalska Republika (Instituto Politécnico de Coimbra)

Prof. dr. sc. Martin Bobinac - Republika Srbija (Šumarski fakultet Beograd)

Prof. dr. sc. Zvezda Bogevska - Republika Sjeverna Makedonija (Fakultet za zemjodelski nauki i hrana Skopje)

Dario Bognolo, mag. ing. - Republika Hrvatska (Veleučilište u Rijeci)

Prof. dr. sc. Agata Cieszewska - Republika Poljska (Szkoła Główna Gospodarstwa Wiejskiego w Warszawie)

Dr. sc. Bogdan Cvjetković, prof. emeritus - Republika Hrvatska (Agronomski fakultet Zagreb)

Prof. dr. sc. Duška Curić - Republika Hrvatska (Prehrambeno-biotehnološki fakultet Zagreb)

Prof. dr. sc. Margarita Davitkovska - Republika Sjeverna Makedonija (Fakultet za zemjodelski nauki i hrana Skopje)

Prof. dr. sc. Dubravka Dujmović Purgar - Republika Hrvatska (Agronomski fakultet Zagreb)

Prof. dr. sc. Josipa Giljanović - Republika Hrvatska (Kemijsko-tehnološki fakultet u Splitu)

Prof. dr. sc. Semina Hadžiabulić - Bosna i Hercegovina (Agromediteranski fakultet Mostar)

Prof. dr. sc. Péter Honfi - Mađarska (Faculty of Horticultural Science Budapest)

Prof. dr. sc. Mladen Ivić - Bosna i Hercegovina (Univerzitet PIM)

Doc. dr. sc. Anna Jakubczak - Republika Poljska (Uniwersytet Technologiczno-Przyrodniczy w Bydgoszczy)

Doc. dr. sc. Orhan Jašić - Bosna i Hercegovina (Filozofski fakultet Tuzla)

Prof. dr. sc. Tajana Krička - Republika Hrvatska(Agronomski fakultet Zagreb)

Doc. dr. sc. Dejan Kojić - Bosna i Hercegovina (Univerzitet PIM)

Slobodan Kulić, mag. iur. - Republika Srbija (Srpska ornitološka federacija i Confederation ornitologique mondiale)

Prof. dr. sc. Biljana Lazović - Crna Gora (Biotehnički fakultet Podgorica)

Prof. dr. sc. Branka Ljevnaić-Mašić - Republika Srbija (Poljoprivredni fakultet Univerziteta u Novom Sadu)

Doc. dr. sc. Zvonimir Marijanović - Republika Hrvatska (Kemijsko-tehnološki fakultet u Splitu)

Doc. dr. sc. Ana Matin - Republika Hrvatska (Agronomski fakultet Zagreb)

Prof. dr. sc. Bosiljka Mustać - Republika Hrvatska (Sveučilište u Zadru)

Hrv. akademik prof. dr. sc. Stanislav Nakić - Bosna i Hercegovina (Sveučilište Hercegovina Mostar)

Prof. dr. sc. Ayșe Nilgün Atay - Republika Turska (Mehmet Akif Ersoy University - Burdur, Food Agriculture and Livestock School) Prof. dr. sc. Tatjana Prebeg - Republika Hrvatska (Agronomski fakultet Zagreb)

Prof. dr. sc. Bojan Simovski - Republika Sjeverna Makedonija (Fakultet za šumarski nauki, pejzažna arhitektura i ekoinženering "Hans Em" Skopje)

Prof. dr. sc. Davor Skejić - Republika Hrvatska (Građevinski fakultet Zagreb)

Akademik prof. dr. sc. Mirko Smoljić, prof. v. š. - Republika Hrvatska (Sveučilište Sjever, Varaždin/Koprivnica, Odjel ekonomije)

Prof. dr. sc. Nina Šajna - Republika Slovenija (Fakulteta za naravoslovje in matematiko)

Dr. Marko Šare - Republika Italija (Hrvatska zajednica u Trstu)

Akademik prof. dr. sc. Refik Šećibović - Bosna i Hercegovina (Visoka škola za turizam i menadžment Konjic)

Prof. dr. sc. Andrej Šušek - Republika Slovenija (Fakulteta za kmetijstvo in biosistemske vede Maribor)

Prof. dr. sc. Elma Temim - Bosna i Hercegovina (Agromediteranski fakultet Mostar)

Mr. sc. Merima Toromanović - Bosna i Hercegovina (Biotehnički fakultet Univerziteta u Bihaću)

Prof. dr. sc. Marko Turk - Ruska Federacija (University of Tyumen)

Doc. dr. sc. Ivana Vitasović Kosić - Republika Hrvatska (Agronomski fakultet Zagreb)

Doc. dr. sc. Ana Vujošević - Republika Srbija (Poljoprivredni fakultet Beograd)

Sandra Vuković, mag. ing. - Republika Srbija (Poljoprivredni fakultet Beograd)

Prof. dr. sc. Vesna Židovec - Republika Hrvatska (Agronomski fakultet Zagreb)

Grafička priprema: Ančica Sečan, mag. act. soc.

Objavljeno: 30. lipnja 2021. godine.

Časopis izlazi u elektroničkom izdanju dva puta godišnje, krajem lipnja i prosinca, a predviđena su i dva specijalna izdanja tijekom godine iz biotehničkog područja.

Časopis je besplatan. Rukopisi i recenzije se ne vraćaju i ne honoriraju.

Autori/ce su u potpunosti odgovorni/e za sadržaj, kontakt podatke i točnost engleskog jezika.

Umnožavanje (reproduciranje), stavljanje u promet (distribuiranje), priopćavanje javnosti, stavljanje na raspolaganje javnosti odnosno prerada u bilo kojem obliku nije dopuštena bez pismenog dopuštenja Nakladnika.

Sadržaj objavljen u Glasilu Future može se slobodno koristiti u osobne i obrazovne svrhe uz obvezno navođenje izvora. 


\section{Glasilo Future}

\section{Stručno-znanstveni časopis}

FUTURA - stručno-znanstvena udruga za promicanje održivog razvoja, kulture i međunarodne suradnje, Bana Josipa Jelačića 13 a, 22000 Šibenik, Hrvatska

(2021) 4 (2-3) 01-85

\section{SADRŽAJ:}

Izvorni znanstveni rad (original scientific paper)

Str.

E. Delić, B. Dorbić, Alisa Adžemović

Dendroflora Donatim parka u Adapazariju/Sakarija - Republika Turska

Dendroflora of Donatım park in Adapazari/Sakarya - Republic of Turkey

\section{Pregledni rad (scientific review)}

Tatjana Prebeg, Kristina Balen, Vesna Židovec

Utjecaj anatomske građe latica na ukrasna svojstva cvjetova

The influence of petal anatomy on ornamental attributes of flowers

Jelica Galić

Značaj proučavanja stanovništva u cilju razvoja poljoprivrede - studija slučaja Županije

Zapadnohercegovačke

The importance of population studies for agricultural development - case study of the West

Herzegovina County

\section{Stručni rad (professional paper)}

D. Krstonošić, Franciska Erdelj, Ž. Škvorc, K. Sever

Odabir autohtonih aromatičnih i ljekovitih trajnica za uređenje terapijskih urbanih prostora na Mediteranu

Selection of autochthonous aromatic and medicinal perennials for therapeutic urban spaces in the Mediterranean

Dubravka Dujmović Purgar, Mateja Palčić, Klara Barić, D. Jareš, Z. Svečnjak Agronomska i gospodarska vrijednost facelije Agronomic and economic value of phacelia

\section{Nekategorizirani rad (uncategorised paper)}

B. Dorbić

Društvene vijesti i obavijesti

Social news and announcements

Zdenka Bilušić, B. Dorbić

Prikaz radionice

Review of workshop 


\title{
Značaj proučavanja stanovništva u cilju razvoja poljoprivrede - studija slučaja Županije Zapadnohercegovačke
}

\section{The importance of population studies for agricultural development - case study of the West Herzegovina County}

\author{
Jelica Galic ${ }^{1 *}$
}

pregledni rad (scientific review)

doi: $10.32779 /$ gf.4.2-3.3

Citiranje/Citation $^{2}$

\section{Sažetak}

U ovom se radu analizira značaj stanovništva u cilju razvoja poljoprivrede Županije Zapadnohercegovačke. Tijekom 20. stoljeća zabilježena je snažnu vanjska i unutarnja migracija koja je prvenstveno bila uzrokovana gospodarskim i političkim obilježjima. Zbog agrarne prenaseljenosti, visokog prirodnog prirasta seoskog stanovništva i krize u agrarnoj proizvodnji kao i pogoršanja društveno-gospodarskih prilika stanovništvo je bilo primorano na iseljavanje. Ubrzana deagrarizacija i deruralizacija u većini zemalja nakon Drugoga svjetskog rata nisu bili adekvatno propraćeni otvaranjem novih radnih mjesta u sekundarnim i tercijarnim djelatnostima.

Društveno-gospodarske prilike nakon Drugoga svjetskog rata poticale su preseljenje iz pasivnih ruralnih krajeva u urbane centre. Ta neravnoteža znatno je doprinijela destabilizaciji i depopulaciji ruralnih krajeva. Suvremeni demografski procesi nisu utjecali samo na prerazmještaj stanovništva i njegovu strukturu već i na transformaciju prostora te napuštanje nekadašnjih poljoprivrednih i pašnjačkih površina. Depopulaciju i izumiranje pojedinih naselja nije moguće zaustaviti, stoga nije realno očekivati njihov oporavak. S obzirom na suvremene demografske trendove velika je vjerojatnost da će poljoprivreda kao i neka naselja u brdsko-planinskim područjima mnogih zemalja u potpunosti izumrijeti.

Ključne riječi: demografija, stanovništvo, depopulacija, deagrarizacija i poljoprivreda.

\footnotetext{
${ }^{1}$ Sveučilište Hercegovina, Fakultet društvenih znanosti Dr. Milenka Brkića, Kraljice Mira 3a, Bijakovići 88266, Međugorje, Republika Bosna i Hercegovina.

* E-mail: jelica.galic@tel.net.ba.

${ }^{2}$ Galić, J. (2021). Značaj proučavanja stanovništva u cilju razvoja poljoprivrede - studija slučaja Županije Zapadnohercegovačke. Glasilo Future, 4(2-3), 30-42. / Galić, J. (2021). The importance of population studies for agricultural development - case study of the West Herzegovina County. Glasilo Future, 4(2-3), 30-42.
} 


\section{Abstract}

This paper analyzes the importance of population studies for agricultural development of the West Herzegovina County. During the 20th century, strong external and internal migration was recorded, which was primarily caused by economic and political characteristics. Due to agrarian overpopulation, high natural population growth and the crisis in agricultural production as well as deteriorating socioeconomic conditions, the population was forced to emigrate. Accelerated deagrarization and deruralization in most post-World War II countries were not adequately accompanied by the creation of new jobs in secondary and tertiary activities.

Socio-economic conditions after World War II encouraged relocation from passive rural areas to urban centers. This imbalance has significantly contributed to the destabilization and depopulation of rural areas. Modern demographic processes have affected not only the relocation of the population and its structure, but also the transformation of space and the abandonment of former agricultural and pasture areas. Depopulation and extinction of certain settlements cannot be stopped, so it is not realistic to expect their recovery. Taking modern demographic trends into consideration, it is very likely that agriculture as well as some settlements in the hilly and mountainous areas of many countries will disappear completely.

Key words: demography, population, depopulation, deagrarization and agriculture.

\section{Uvod}

Demografija je znanost o stanovništvu ili znanost koja proučava stanovništvo, a za te potrebe integrira niz ostalih znanosti kao što su povijest, sociologija, ekonomija, logika, statistika i mnoge druge. U središtu zanimanja suvremene geografije stanovništva i njenog pristupa prostornim procesima i prostornoj interakciji jeste dinamika stanovništva, posebice prostorni razmještaj ljudskih resursa (Nejašmić, 2005).

Prava bit geografije stanovništva je analiza i objašnjenje složenih međusobnih veza između fizičkog i društvenog okoliša s jedne strane, te stanovništva s druge strane (Clarke, 1965). Demografska kretanja nedvojbeno utječu na korištenje prirodnih resursa, stoga je s ciljem zaštite od prekomjerne eksploatacije prirodnih bogatstava nužno pratiti i analizirati kvantitativne i kvalitativne populacijske promjene. Usporedo s brojnim problemima koji su se počeli pojavljivati u društvu i naseljenim dijelovima svijeta tijekom 20. stoljeća, a kao posljedica iznimno brzog porasta broja stanovnika i potrošnje dobara, povećavao se i interes znanstvenika, šire javnosti i vlada pojedinih država za populacijske probleme na svim razinama, od globalnih do lokalnih (Jones, 1990). Pojam nosivosti prostora odnosi se na broj ljudi koji mogu živjeti na određenom prostoru na osnovi fizičkih resursa i načina na koji se ti resursi rabe da ne bi došlo do njihovog potpunog iscrpljivanja (Miller, 1998). 
Sastav prema dobi po svojim je društveno-gospodarskim utjecajima jedna od najvažnijih značajki stanovništva. Ona odražava biodinamiku i potencijalnu vitalnost stanovništva nekog područja. Promjene u dobnom sastavu stanovništva sadržavaju dva usporedna globalna demografska procesa: smanjivanje udjela mladih uz istovremeno povećavanje udjela starog stanovništva (Friganović, 1990).

Nedostatak stalnih prihoda, visoka prosječna dob, niska stopa obrazovanja, zapuštenost graditeljskog nasljeđa, nezadovoljavajuća opremljenost osnovnim uslugama $i$ infrastrukturom te nesređena imovinska situacija imaju za posljedicu zapuštanje ruralnih naselja i gubitak mlađeg i radno sposobnog stanovništva.

Suvremeni demografski procesi su utjecali na napuštanje nekadašnjih poljoprivrednih površina te depopulaciju većeg broja naselja u brdsko-planinskim područjima. Stoga je značajno proučavanje stanovništva u cilju razvoja poljoprivrede. Tako npr. o uzgoju i proizvodnji duhana u Hercegovini i životu stanovništva naroda ovih prostora pisali su Alilović (1976) i Markotić (1983). Isti autori analiziraju i zemljopisne osnove uzgoja duhana u općini Ljubuški kao o kretanju stanovništva u doba industrijalizacije u Bosni i Hercegovini. Roglić (1954) analizira kretanje stanovništva i značaj polja u zapadnoj Bosni i Hercegovini. O naseljenosti sjevernih - planinskih dijelova županije, nekad i sada, pisao je Krasić (1996). Danas u Hrvatskoj županije nastoje različitim mjerama potaknuti razvoj ruralnih područja, a u zadnje vrijeme i putem ruralnog turizma (Svržnjak et al., 2020). Ruralni turizam važan je faktor u aktivaciji i održivom razvoju ruralnih područja, a pomaže prilikom očuvanja lokalnog identiteta,čuva okoliš, tradiciju i običaje, jača lokalnu, tradicijsku i ekološku proizvodnju te pomaže razvoju ruralnih krajeva po principima održivog razvoja (Marušić, 2017). Razvitku agroturizma u ruralnim područjima hrvatske idu na ruku i nove mjere razvojne politike Europske unije, koja razvoj ovog oblika turizma vidi kao sredstvo u cilju razvoja ruralnih područja (Pamuković et al., 2016). U našoj državi i šire u ruralnim sredinama prevladavaju izrazito mali obiteljski posjedi koji ne mogu osigurati zadovoljavajući standard života za mlade ljude.

Rezultati istraživanja koje su proveli Pejnović et al. (2017) potvrđuju značaj zadrugarstva kao faktora teritorijalne kohezije, kao i visok stupanj pozitivne korelacije između stagnacije u regionalnom tj. ruralnom razvoju. Ruralni prostor u Hrvatskoj je u najvećoj mjeri zahvaćeni procesima ekstremne depopulacije i ekonomske stagnacije. Na razini modela za lokalni razvoj bilježi se primjer suvremenih održivih zajednica, ekosela (Bokan, 2016).

Bitan faktor proučavanja stanovništva jest i njegov razmještaj; suvremeni razvitak implicirao je i potakao koncentraciju stanovništva na pojedinim dijelovima Zemlje što je rezultiralo nastankom većih i manjih naselja koja su, kao nositelji gospodarskog razvitka, uglavnom jačala. S druge strane, brojni su prostori depopulacijski što postaje ograničavajućim čimbenikom daljnjeg razvitka. Nadalje, važnost proučavanja stanovništva ogleda se i u vezi koju stanovništvo ostvaruje s okolinom. S obzirom na ubrzani rast stanovništva i njegovu sve veću koncentraciju u gradovima riječ je uglavnom o 
intenzivnoj degradaciji okoliša, što za sobom nosi brojne druge posljedice koje na kraju mogu rezultirati ograničavajućim čimbenikom za daljnji razvitak stanovništva (Nejašmić, 2005).

Migracijska kretanja stanovništva usko su povezana i s procesima industrijalizacije, koja su zahvatila prostore izvan ruralne zone. To je uzrokovalo napuštanje poljoprivrede kao glavne gospodarske grane i zapošljavanje u industriji i uslužnom sektoru izvan naselja. Najvažniji čimbenici koji su utjecali na deagrarizaciju i deruralizaciju svakako su industrijalizacija i urbanizacija koje su se intenzivirale u drugoj polovici 20. stoljeća. Zahvaljujući tercijarizaciji ekonomije i društva smanjila se ovisnost o primarnim djelatnostima, obiteljskim gospodarstvima i ruralnim područjima, a povećalo se zapošljavanje u industriji i uslužnim djelatnostima. Posljedica toga bio je ruralni egzodus te veća samostalnost mlađih generacija (Galić, 2015).

Demografski razvoj ne ovisi samo o procesima na nekom području, već i o funkcijama i demografskim kretanjima širih područja. Samo povijesno-geografska perspektiva može prikazati razvoj stanovništva tijekom proteklih desetljeća i stoljeća, koji je važan za razumijevanje određenih procesa; može otkriti odnos između rasta i smanjenja broja stanovnika i promjene u ekonomiji i okolini te kako su ti procesi utjecali na stvaranje geografske okoline kakvu danas poznajemo (Coleman i Salt, 1992).

U desetljećima nakon Drugoga svjetskog rata dogodile su se brojne korjenite promjene u društvu te $u$ ulogama pojedinih država što se ogledalo u brojnim sferama života: geopolitičkoj (npr. Hladni rat, osamostaljenje bivših kolonija), ekonomskoj (primjerice jačanje privrede pojedinih svjetskih država, porast međunarodne trgovine), kulturnoj (npr. jačanje sekularizma) te u društvenim odnosima (npr. pojave nemira u gradovima, povećana zaposlenost žena).

Usporedo s tim promjenama koje su se odražavale u veličini, rastu i ponašanju određenih populacijskih skupina, jačao je i interes za proučavanjem stanovništva s različitih stajališta (Bailey, 2005).

\section{Stanovništvo i deagrarizacija - studija slučaja Županije Zapadnohercegovačke}

Stanovništvo sa svojim osnovnim obilježjima poput broja, razmještaja, strukture i prostorne pokretljivosti, ima izuzetno značajan utjecaj na oblikovanje životnog prostora te organiziranje društveno-gospodarskog života, zato se svaka promjena u populacijskim obilježjima odražava u organizaciji života na određenom prostoru. Međutim, za određivanje smjernica razvojnih strategija nužno je poznavati prirodno-geografske i ljudske potencijale, stoga se proučavanjem stanovništva s različitih stajališta bave brojne znanosti i znanstvene discipline. Budući da je predmet istraživanja tih znanstvenih disciplina isti (stanovništvo), jasno je zašto se često smatra da je granica između demografije, statistike, ekonomije, sociologije i geografije stanovništva dosta nejasna (Woods, 1982). 
Istraživanje stanovništva najčešće se temelji na proučavanju triju osnovnih sastavnica populacijskih kretanja - rađanja, umiranja i prostorne pokretljivosti. Pored toga proučavaju se i struktura stanovništva i demografske promjene.

Čimbenici koji su utjecali na deagrarizaciju i deruralizaciju svakako su industrijalizacija i urbanizacija. Dobar primjer napuštanja agrara je Županija Zapadnohercegovačka u Bosni i Hercegovini koja je tradicionalno emigracijsko područje koje već desetljećima depopulira. Brojni su stanovnici ovoga kraja napustili prostore i otišli živjeti drugdje, što je pospješilo i ubrzalo procese deagrarizacije i deruralizacije. Promjene u broju stanovnika na razini naselja zamjećuje se kako je nakon 70-tih godina 20. stoljeća došlo do konačnoga demografskoga sloma hercegovačkoga sela (Galić, 2015).

Također je selo doživjelo i promjenu odnosa prema prirodi koju se sve više iskorištava, a sve manje održava. Prema Šundaliću (2009) ekocentrična i naturocentična dimenzija života na selu zamijenjena je pragmatičnom i tehnocentričnom.

Depopulacija je najprije počela u naseljenim mjestima planinskog dijela Županije Zapadnohercegovačke iz razloga napuštanja tradicionalnih gospodarskih aktivnosti, u prvom redu poljoprivrede (uzgoj duhana i stočarstva). Duhan je bio stoljetni simbol i Hercegovine i njenog specifičnog tla, no danas rijetka su mjesta gdje se duhan uzgaja (Slika 1 i 2). Poneka domaćinstva to i danas čine, ali uglavnom u ograničenim količinama i može se slobodno kazati kako je ova kultura, koja je osiguravala životnu egzistenciju sveukupnog stanovništva, skoro u potpunosti nestala (Mikulić, 2013).

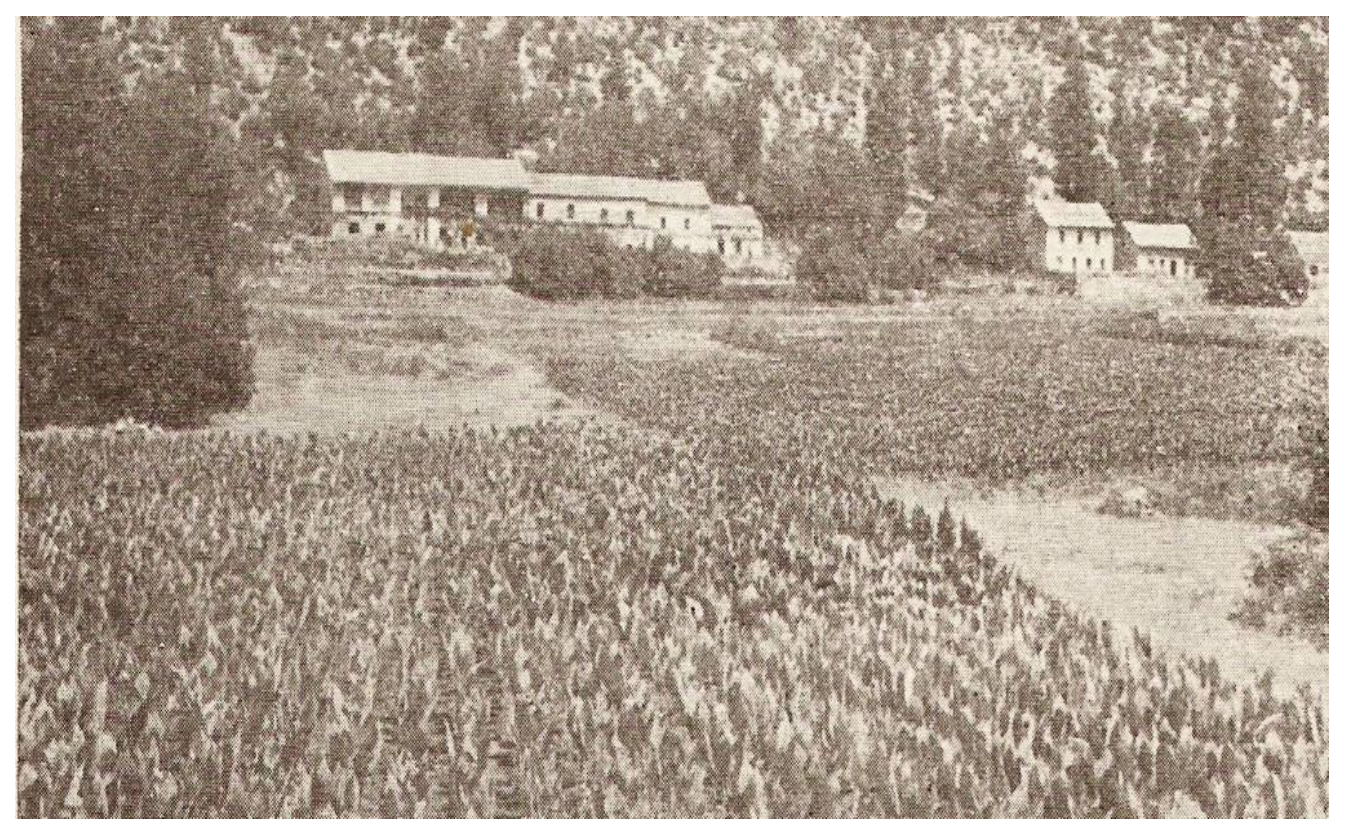

Slika 1. Uzgoj duhana u Klobuku (crvenica na dolomitu) (Izvor: Delač, 1952)

Figure 1. Tobacco growing in Klobuk (red soil) (Source: Delač, 1952) 


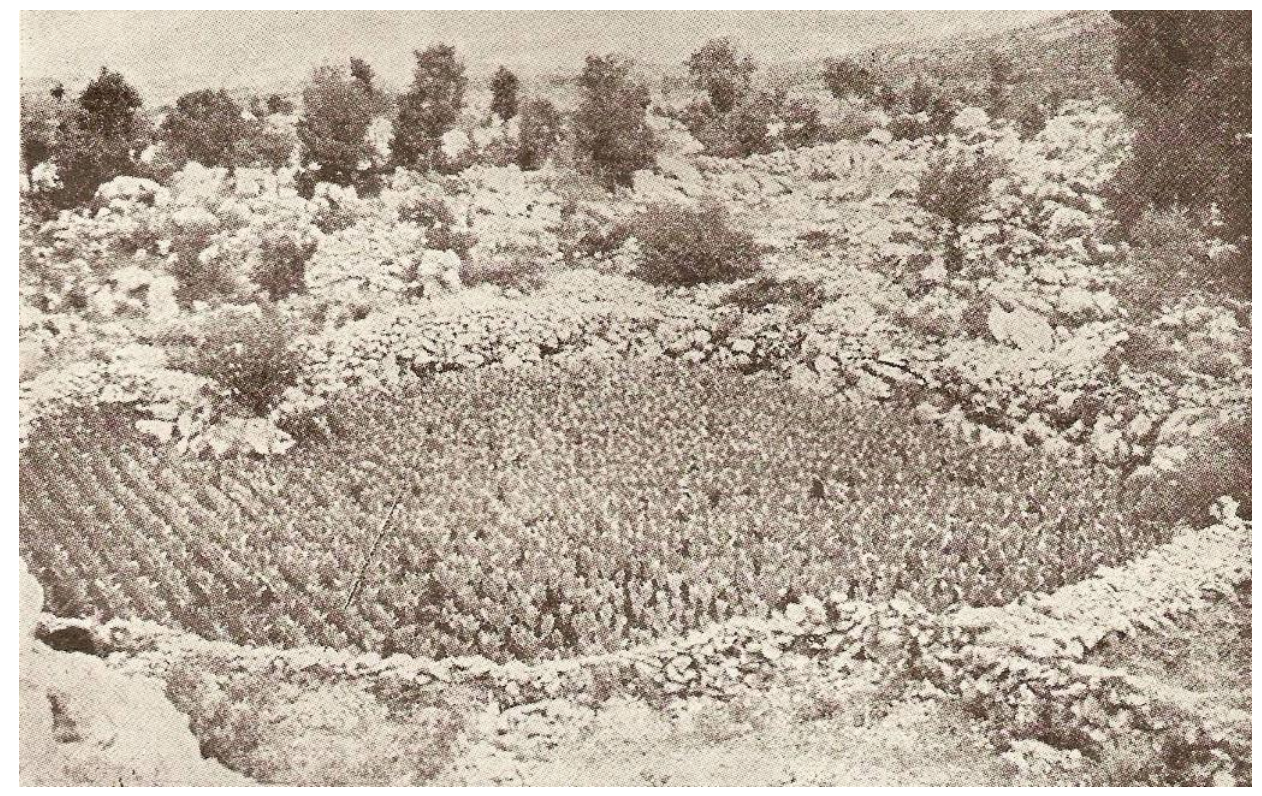

Slika 2. Duhan u krškim ponikvama (Izvor: Delač, 1952)

Figure 2. Tobacco in karst sinkholes (Source: Delač, 1952)

Od 70-tih godina prošlog stoljeća stočarska ekonomija (prvenstveno uzgoj ovaca) postepeno prestaje, a s time i jedna od osnovnih komponenata za uzgoj duhana - stajski gnoj. Radna snaga, kao bitan faktor uzgoja i obrade duhana, u ovom se razdoblju rapidno smanjuje što generira sljedeće sociodemografske pojave: opadanje nataliteta, školovanje djece za zanimanja izvan poljoprivrede te, najvažnije, vrlo snažnu emigraciju radne snage u srednju, zapadnu i sjevernu Europu. Koncem osamdesetih godina prošlog stoljeća proizvodnja duhana u Hercegovini doživljava krah. Više je činitelja koji su doprinijeli krizi duhana u Hercegovini, no najvažniji su ekonomski i tržišni, a dijelom tehnološki i demografski. Sve se na kraju svodi na neatraktivnu cijenu, kako u otkupu tako i u prodaji. Od nekadašnje biljke hraniteljice, kulture s kojom se živjelo, za koju se živjelo i od koje se živjelo, duhan u Hercegovini postaje stvar prošlosti s dobrim izgledima da ostane samo poglavlje u povijesnim knjigama (Galić, 2010).

U Dalmaciji i Hercegovini tijekom povijesti je bio važan uzgoj i sakupljanje različitih vrsta ljekovitog bilja. U Zapadnohercegovačkoj županiji još i danas postoje tzv. travari koji lijeće različite ljudske tegobe. Ova proizvodnja zbog deagrarizacije i usitnjenih parcela također nije doživjela svoj procvat premda je veoma pogodna i perspektivna. U posljednje vrijeme poznat je "slučaj" sa smiljem kada su zbog dobre tržišne cijene iskrčeni mnogi tereni na različitim tipovima tala na području Dalmacije i Hercegovine.

\section{Depopulacija i ostarjelost stanovništva - studija slučaja}

Promjena broja stanovnika u određenom razdoblju rezultat je interakcije triju procesa: rađanja, umiranja i migracije, koji čine dinamičke komponente promjene broja stanovnika, a rezultiraju 
porastom, smanjenjem ili stagnacijom. Na interakciju ovih triju komponenti značajan utjecaj imaju određeni prostorni i socioekonomski čimbenici te napredak tehnologije (Slika 3). Dakle, u prostornovremenskoj interakciji ovih triju komponenata dolazi do promjena u broju stanovnika, gustoći naseljenosti i sastavu (Barret, 1992).

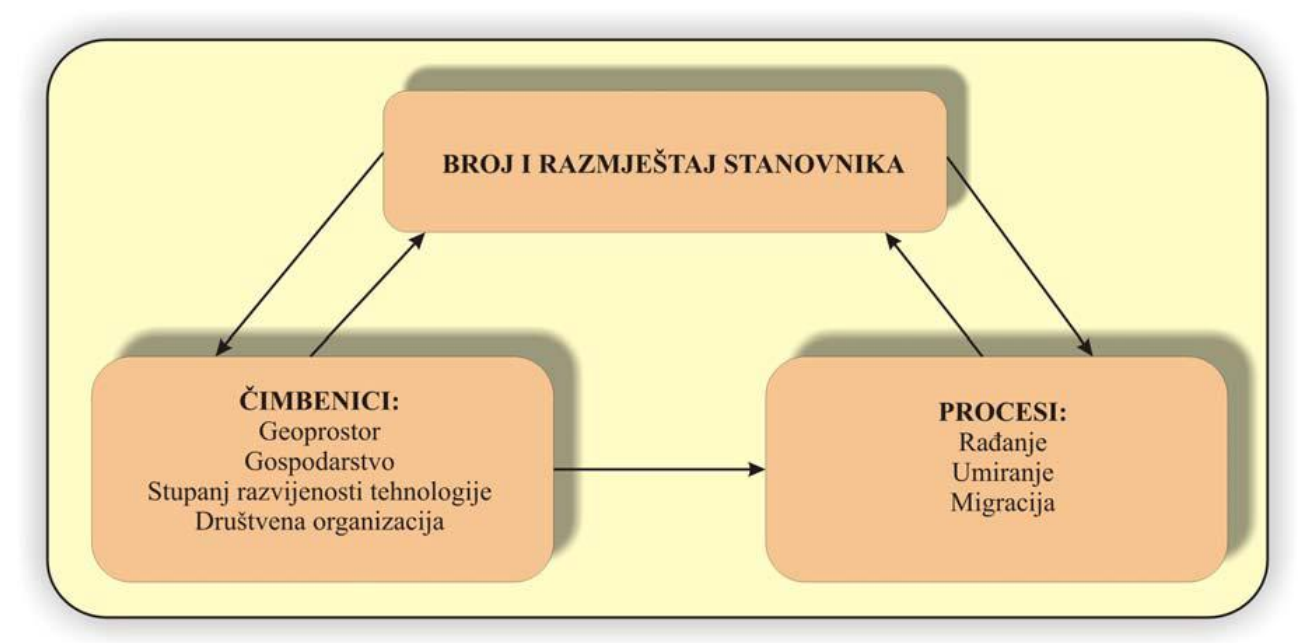

Slika 3. Čimbenici i procesi koji utječu na broj i razmještaj stanovnika (Izvor: Barret, 1992)

Figure 3. Factors and processes affecting population size and distribution (Source: Barret, 1992)

Ukoliko se usporedi prirodno kretanje stanovništva gradskih središta i ostalih naselja u Županiji Zapadnohercegovačkoj, jednoj od deset županija/kantona u Bosni i Hercegovini, mogu se uočiti određene razlike. Naime, osim što se broj stanovnika smanjio u odnosu na prijeratno stanje, narušio se i dobno-spolni sastav stanovništva te je došlo do izrazitog smanjenja broja mladog, fertilnog stanovništva, uz istodobno povećanje starog. Time je znatno smanjen bioreprodukcijski potencijal te je u pitanje doveden opstanak velikog broja naselja. Na temelju prirodnog kretanja pojedinih skupina zapadnohercegovačkih ruralnih naselja, moguće je zaključiti kako pojedinim selima prijeti izumiranje, pogotovo ako se u obzir uzme težnja velikog broja mladih za preseljenjem u grad. Ruralna su područja nekoć bila nositelji bioreprodukcije zapadnohercegovačkog stanovništva. Međutim, intenzivnim preseljavanjem iz tradicionalno visokonatalitetnih (ruralnih) krajeva u niskonatalitetne (urbana područja) došlo je do izmjene prostornih razlika u prirodnom kretanju. Naime, došlo je do svojevrsnog apsurda - gradovi, koji su ovom promjenom trebali postati težište bioreprodukcije gotovo su se izjednačili u stopama rodnosti s neurbanim naseljima koje obilježava intenzivnija depopulacija i veći stupanj ostarjelosti stanovništva (Galić, 2015).

\section{Primarni sektor u gospodarskoj strukturi}

Gospodarska struktura stanovništva u užem smislu podrazumijeva strukturu stanovništva prema aktivnosti, djelatnosti i zanimanju, a u širem smislu uključuje i položaj u zanimanju, sektor vlasništva, kućanstva prema izvorima prihoda, veličini posjeda i slično (Nejašmić, 2005). Podatci o dinamici, 
strukturi i distribuciji gospodarski aktivnog stanovništva ili radne snage izuzetno su važni za formuliranje politike i primjenu programa o punom i učinkovitom korištenju ljudskih resursa u nekoj zemlji (Wertheimer-Baletić, 1999).

Budući da ne sudjeluju u procesu rada, stanovništvo s osobnim prihodom i uzdržavano stanovništvo čine ekonomski neaktivno stanovništvo. Zaposlenost stanovništva po sektorima djelatnosti značajan je pokazatelj stupnja gospodarskog razvoja određenog prostora. Djelatnosti se najčešće grupiraju u četiri osnovne skupine gospodarskih djelatnosti: primarni, sekundarni, tercijarni sektor i kvartarni (Nejašmić, 2005).

U prvoj polovici 20. stoljeća velik je dio aktivnog stanovništva bio zaposlen u primarnom sektoru. Nakon toga jeste globalni proces smanjenja udjela zaposlenih u poljodjelstvu. Razvoj industrijskih djelatnosti imao je za rezultat povećanje broja radnih mjesta u tom sektoru, a istovremeno je došlo do opadanja broja zaposlenih u poljodjelstvu zbog tehnološkog napretka, i s time povezanog smanjenja potrebe za brojnom radnom snagom. Neprimjerena razvojna politika poticala je napuštanje poljodjelstva i ruralnih krajeva što je dovelo do propadanja sela i agrara (Crkvenčić, 1981).

U primarnom gospodarskom sektoru, kao najistaknutija grana gospodarstva javlja se poljoprivreda. Rezultat svega je zapostavljanje poljodjelstva i povećanje površina pod trajnim socijalnim ugarom. Krajem prošlog stoljeća kao najznačajniji sektor djelatnosti izdvojio se sekundarni sektor i jačanje uslužnih djelatnosti. Istodobno, nije se vodilo računa o modernizaciji poljodjelstva čime je došlo do ugrožavanja egzistencije velikog dijela populacije te preorijentiranja na djelatnosti sekundarnog $\mathrm{i}$ tercijarnog sektora. Također je došlo do znatnog iseljavanja stanovništva iz nekad poljoprivrednih dijelova u gradska i prigradska naselja (Crkvenčić, 1981).

Društveno-gospodarske prilike nakon Drugoga svjetskog rata poticale su preseljenje iz pasivnih ruralnih krajeva u urbane centre. Uslijed iseljavanja mladog, radnoaktivnog stanovništva došlo je do nerazmjera između demografskih resursa $u$ gradskim naseljima i ruralnim dijelovima. Navedena neravnoteža znatno je doprinijela destabilizaciji i depopulaciji ruralnih krajeva (Wertheimer-Baletić, 1999).

$\mathrm{Na}$ "štetu" ondašnjeg agrara nakon Drugog svjetskog rata usporedno su se odvijala dva procesa: industrijalizacija i deagrarizacija. U jednoj pretežno agrarnoj zemlji industrijalizacija se mogla izvesti jedino na način prelijevanja dohotka iz poljoprivrede i masovnog angažiranja jeftine ruralne radne snage (Defilipis, 2006).

Za Dalmaciju i susjednu Hercegovinu karakterističan je masovni odlazak stanovništva sa sela i prijelaz s monokulturne poljoprivrede na složeniju ekonomsku strukturu sela što su dva društvena procesa koja su značajno obilježila ovo drugo razdoblje. Pod njihovim utjecajem selo i poljoprivreda se mijenjaju: obradive površine i to one koje se ne mogu obraditi mehaničkim strojevima se napuštaju; obiteljska 
gospodarstva uvode mehanizaciju, bez obzira na površinu, u proizvodnji se primjenjuju reprodukcijski materijal, proizvodnja se intenzivira - mijenja se proizvodna struktura: opada proizvodnja žitarica, raste povrtlarska i voćarska proizvodnja, obnavljaju se masline i zasnivaju mladi nasadi, stočni fond stagnira ili opada, selo se urbanizira i gradi u svakom pogledu. Unatoč navedenim gospodarskim promjenama i porastu životnoga standarda na selu, ono se i dalje demografski prazni (Defilipis, 2006).

Danas je u Dalmaciji i Hercegovini ostala poljoprivreda malih dimenzija, mješovitih domaćinstava, a proizvodnja služi za podmirenje vlastitih ili pak lokalnih potreba. Upravo ta "lokalna" obilježja bit će činilac opstanka i razvoja ovoga oblika proizvodnje. Jačanjem zadruga kao i državnim mjerama poticaja, potrebna je pomoć takvoj proizvodnji Njena uloga je i održavanje tradicionalnog agrarni krajobraz (Slika 4) što će pridonijeti specifičnoj prepoznatljivosti područja (Defilipis, 2006).

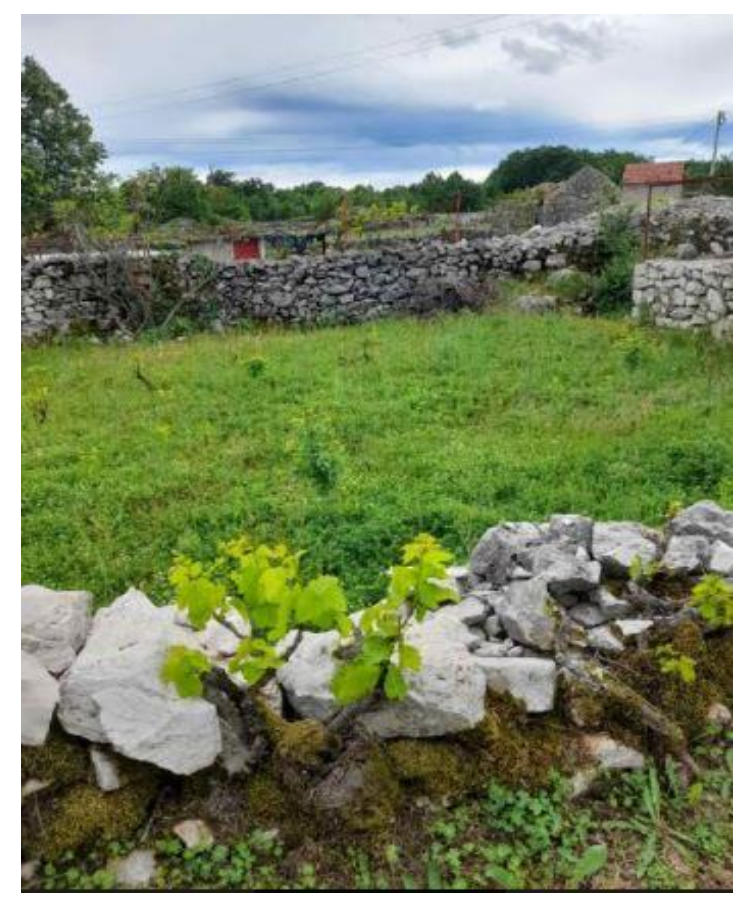

Slika 4. Suhozidovi u Hercegovini, element agrarnog krajobraza (Foto: J. Galić, 2021)

Figure 4. Drywall in Herzegovina, an element of the agrarian landscape (Photo: J. Galić, 2021)

Istodobno, razina obrazovanosti dosegla je razinu na kojoj u razvijenim zemljama većina stanovništva ima završenu srednju školu, a žene su po tom pitanju dostigle muškarce. Obrazovanje i urbanizacija omogućile su ženama preseljenje u urbane sredine koje su pružale mogućnost zaposlenja u tercijarnim djelatnostima. Tranzicijom iz jednostavne poljoprivredne ekonomije u industrijsku, djeca više nisu bila izvor radne snage u kućanstvu jer mladi ljudi u poljoprivrednom društvu od malih nogu pomažu u obavljanju poljoprivredne djelatnosti (Kaplan, 1996), dok u industrijskom i postindustrijskom društvu odgoj djece zahtijeva i njihovo školovanje koje može biti dugotrajno i skupo. Istraživanja su također pokazala da su roditelji, posebice majke, koji imaju manje djece zdraviji i žive dulje te tako mogu uložiti svoje napore u odgajanje manjeg broja djece i osigurati im kvalitetniji život (Preston i Haines, 1991). 
Županija Zapadnohercegovačka zaista je dobar primjer prostora u kojem je polarizirani razvoj doveo do depopulacije pojedinih dijelova, posebice udaljenih, uglavnom brdskih sela, i koncentracije stanovništvu u gradu kao i prigradskim naseljima, pa je stoga danas teško zaustaviti negativne trendove koji su već desetljećima prisutni na ovom prostoru. Većina obradivog poljoprivrednog zemljišta se ne obrađuje što je posljedica nepostojanja jasne državne strategije te rastućeg segmenta uvoza poljoprivrednih proizvoda. Potpuna deagrarizacija posebno je izražena u pojedinim naseljima, u kojima je poljoprivreda stoljećima bila najvažnija gospodarska djelatnost, ali i način života. Depopulacija na brdskom i planinskom području ima negativne posljedice na funkcije naselja te dolazi do zamiranja pojedinih gospodarskih djelatnosti (zemljoradnje i stočarstva) (Galić, 2015).

Intenzitet migracija različit je u pojedinim naseljima, no razdoblje od 1980-tih može se okarakterizirati kao vrijeme kada je depopulacija zahvatila čitavu zapadnu Hercegovinu. Već početkom sedamdesetih godina 20. stoljeća jasno su se očitovale posljedice dugotrajne depopulacije ruralnih prostora Županije Zapadnohercegovačke i širih prostora u regiji. U narednim desetljećima nastavljaju se nepovoljni demografski procesi koji rezultiraju sve većom koncentracijom stanovništva u gradu te pražnjenjem ruralnih naselja Županije (Galić, 2015).

\section{Zaključak}

Brojni stanovnici ruralnih prostora Županije Zapadnohercegovačke odlaze živjeti drugdje što je pospješilo i ubrzalo procese deagrarizacije i deruralizacije. Jedan od osnovnih razloga zapuštanja poljoprivrednih površina jest nemogućnost navodnjavanja, a tu je i ekonomska neisplativost te nepovoljna dobna struktura stanovništva u kojoj prevladava staro stanovništvo koje je gospodarski neaktivno.

S aspekta demografije svijeta, odnosno kretanja broja stanovništva kroz povijest, može se uočiti da se identificiraju neke temeljne prekretnice tj. povijesni događaji koji su utjecali na intenzivniji rast stanovništva. Pri tome se misli na ljudska dostignuća u osiguranju boljih životnih uvjeta, bilo da se radi o prosperitetu, unapređenju egzistencijalnih uvjeta, napretka medicine i ostaloga. Ističe se da su zemlje s većim brojem stanovnika i većim prirodnim priraštajem te većom stopom nataliteta, često $i$ najsiromašnije zemlje u kojima vlada glad, neobrazovanost i duboka neimaština.

Demografska slika Bosne i Hercegovine je prilično zabrinjavajuća jer će mladog i radno sposobnog stanovništva biti sve manje, a starih sve više (depopulacija, migracija). Ako se ne zaustavi emigracija stanovništva Bosna i Hercegovina će se vrlo vjerojatno suočiti s manjkom vlastite radne snage u budućnosti uzevši u obzir dobnu strukturu i kontingent radno aktivnog stanovništva. Gospodarski razvoj treba temeljiti na iskoristivosti raznolikosti krajeva Bosne i Hercegovine i ulaganju u poljoprivredu u nizinskim područjima. Potrebno je modernizirati poljoprivrednu i industrijsku proizvodnju kako bi se povećala proizvodnost, zadržati mladu i obrazovanu radnu snagu u ruralnim 
područjima koja zbog nemara propadaju i neka od naselja izumiru. Poljoprivreda teško može biti glavni izvor prihoda jer osigurava lakši pristup resursima hrane, ali ne i novcu, visoka je razina neobrađenih oraničnih površina, a zemljište je zapušteno i neuređeno. Osim toga, izrazit je tehnološki zaostatak za Europom jer u poljoprivredi Bosne i Hercegovine dominira zastarjela mehanizacija i tradicionalni pristup proizvodnje.

Državnim mjerama i poticajima svakako treba zadržati stanovništvo u ruralnim područjima i spriječiti regresivna demografska kretanja i depopulaciju kao i provoditi mjere ublažavanja starenja stanovništva u ruralnim naseljima. Kada su u pitanju poljoprivreda i druge djelatnosti, neophodno je izgrađivati alternativnu, održivu poljoprivredu i proizvodnju zdrave hrane, održivo koristiti prirodne resurse, davati efikasnu i stvarnu podršku poljoprivrednicima. Više desetljeća stručnjaci upozoravaju na probleme ruralnog razvoja i razvoja poljoprivrede kao i odlaska mladih iz ruralnih područja.

\section{Literatura}

Alilović, I. (1976). Duhan i život naroda u Hercegovini. Zagreb: Hrvatsko književno društvo svetog Ćirila i Metoda.

Bailey, A. (2005). Making Population Geography. London: Hodder Arnold.

Barrett, H.R. (1992). Population geography (Conceptual Frameworks in Geography). London: Oliver \& Boyd.

Bokan, N. (2016). Ekosela: subpolitični odgovor na neodrživost. Sociologija i prostor, 54 (1 (204)), 45-70.

Clarke, J.I. (1965). Population Geography. Oxford: Pergamon.

Coleman, D., Salt, J. (1992). The British Population - Patterns, Trends, and Processes. Oxford: Oxford University Press.

Crkvenčić, I. (1981). Socijalnogeografski aspekti pojave ugara, odnosno neobrađenih oranica, Geografski glasnik, 43, 95-107.

Defilippis, J. (2006). Promjene u poljoprivredi i selu Dalmacije u posljednjih stotinjak godina. Društvena istraživanja, 15 (6 (86)), 1047-1062.

Delač, I. (1952). Duhansko tlo u Hercegovini u odnosu na kvalitativnu i kvantitativnu proizvodnju duhana, U: Zbornik radova Duhanskog instituta - Mostar, Duhanski institut, Mostar.

Friganović, M. (1990). Demogeografija: Stanovništvo svijeta. Zagreb: Školska knjiga (IV izdanje). 
Galić, J. (2010). Historijski prikaz uzgoja duhana u Hercegovini, Zbornik radova, Odsjek za geografiju, PMF, Univerzitet u Tuzli, Sv. Geografija, 7., 15-168.

Galić, J. (2015). Demografski problemi Zapadnohercegovačke županije i njihov utjecaj na morfološko-funkcionalne promjene naselja, doktorska disertacija, PMF Novi Sad.

Jones, H. (1990). Population geography, 2. Izdanje. London: Paul Chapman Publishing Ltd.

Kaplan, H. (1996). A theory of fertility and parental investment in traditional and modern human societies. Yearbook of Physical Anthropology, 39, 91-135.

Krasić, P. (1996). Naseljenost sjevernih - planinskih dijelova Županije Zapadnohercegovačke. Mostar: Ziral.

Markotić, A. (1983). Demografski razvitak Hercegovine. Mostar: Prva književna komuna.

Marušić, M. (2017). Utjecaj agroturizma na socioekonomski razvoj Primorsko-goranske županije. Agroeconomia Croatica, 7 (1), 109-116.

Mikulić, G. (2013). Županija Zapadnohercegovačka. Grude: Grafotisak.

Miller, G.T. (1998). Environmental Science: Working With The Earth, 7. izdanje, Belmont, CA, Wadsworth Publishing Co.

Nejašmić, I. (2005). Demogeografija: stanovništvo u prostornim odnosima i procesima. Zagreb: Školska knjiga.

Pamuković, A., Dorbić, B., Radeljak, M. (2016). Iskustvo i praksa razvoja agroturizma u europi te njegov utjecaj na Hrvatsku. Agronomski glasnik, 78 (1), 51-64.

Pejnović, D., Radeljak Kaufmann, P., Lukić, A. (2017). Utjecaj zadrugarstva na regionalni i ruralni razvoj Hrvatske. Hrvatski geografski glasnik, 79 (2), 51-85.

Preston, S. H., Haines, M.R. (1991). Fatal Years: Child Mortality in Late Nineteenth-Century America. Princeton: Princeton University Press.

Roglić, J. (1954). Polja zapadne Bosne i Hercegovine. Sarajevo: Geografsko društvo NR BiH.

Svržnjak, K., Hrg Matušin, I., Kantar, S., Despotović, A. (2020). Indeks uspješnosti razvoja ruralnog turizma u Koprivničko-križevačkoj županiji. Agroeconomia Croatica, 10 (1), 46-57.

Šundalić, A. (2009). Ruralni prostor i društvena struktura - novi identitet Slavonije i Baranje. Ekonomski vjesnik, 22 (1), 11-22. 
Weeks, J. R. (1999). Population - An Introduction to Concepts and Issues, 7. Izdanje. Belmont Albany - Boston Wadsworth Publishing Company.

Wertheimer-Baletić, A. (1982). Demografija: Stanovništvo i ekonomski razvitak, II. Izmjenjeno i dopunjeno izdanje. Zagreb: Informator.

Wertheimer-Baletić, A. (1999). Stanovništvo i razvoj. Zagreb: Mate.

Woods, R. I. (1986). Theory and methodology in population geography, u: Population Geography: Progress and Prospects (ur. M. Pacione). London-Sydney: Croom Helm.

Primljeno: 23. ožujka 2021. godine

Prihvaćeno: 30. lipnja 2021. godine
Received: March 23, 2021

Accepted: Jun 30, 2021 